\title{
スパッタ法におけるイオン照射効果制御を用いた薄膜形成技術の開発*
}

豊 田宏*1

\section{Development of Thin Film Formation Technique Using Ion Irradiation Effect Control in Sputtering Method}

Hiroshi TOYOTA*1

\author{
*1Department of Electronics and Computer Engineering, Hiroshima Institute of Technology, \\ 2-1-1 Miyake, Saeki-ku, Hiroshima-shi, Hiroshima 731-5193, Japan
}

(Received April 1, 2016, Accepted October 15, 2016)

\begin{abstract}
We fabricated Ni films on a Polyimide (PI) film and an Acrylonitrile-Butadiene-Styrene (ABS) resin substrate using unbalanced magnetron sputtering assisted by inductively coupled plasma. For the PI film, the effect of ion irradiation was controlled by substrate DC bias $V_{\mathrm{S}}$ and magnetic flux density toward the substrate $B_{\mathrm{C}}$. For the ABS resin substrate, the effect of ion irradiation was controlled by target DC power $P_{\mathrm{T}}$ and magnetic flux density toward the substrate $B_{\mathrm{C}}$. For each substrate, we investigated the effect of ion irradiation on the Ni film structures in detail. The effect of ion irradiation $E$ was estimated by measured physical quantities with respect to sputtered atom flux, ion flux and ion energy. From x-ray diffraction measurement, the crystallite size $t_{(111)}$ increased with the effect of ion irradiation. Minimum film resistivities of $9.0 \times 10^{-6}$ and $1.4 \times 10^{-5} \Omega \mathrm{cm}$ were measured for $B_{\mathrm{C}}=3 \mathrm{mT}$ and $E=0.24$ on the PI film and $B_{\mathrm{C}}=5 \mathrm{mT}$ and $E=0.98$ on the ABS resin substrate, respectively. We conclude that controlling the effect of ion irradiation is effective for high quality Ni film formation on the PI film and the ABS resin substrate.
\end{abstract}

\section{1. はじめに}

近年，電子デバイス応用の多様化に伴い，樹脂素材を基板 に用いたフレキシブル電子デバイスおよびプラスチック電子 デバイスの研究開発が進展している1,2). 従来, 電子デバイ ス作製に打ける薄膜形成には主としてスパッタ法が用いられ ている、スパッタ法に打いて，基板に到達したスパッタ原子 の表面拡散は膜の高密度化, 膜表面の平坦化, 基板と膜の付 着力強化など成膜に重要な役割を果たすことが知られている が3)，この表面拡散は高エネルギー粒子による基板照射また は基板加熱によって促進される，基本的に樹脂基板は低融点 であるため高品質成膜を促すために基板加熱を伴う成膜は困 難である，つまり，樹脂基板上に低温で高品質な成膜を行う ためには基板に及ぼす高エネルギー粒子の基板照射，すなわ ちイオン照射効果を適切に制御することが重要であると考え られる。

樹脂素材の特性は, その種類によって大きく異なる. 代表 的な柔軟性樹脂としてポリイミド（PI）フィルムが挙げら れ，フレキシブルプリント基板を主な用途として電子機器製 品の性能向上に寄与している. また，アクリロニトリルーブ タジエンースチレン (ABS) 樹脂は高い耐衝撃性や剛性など, 優れた機械的特性から電子機器の外装をはじめ工業用途に広 く用いられている.これまでに, 膜応力や基板との密着力な ぞ薄膜の機械的性質に対する知見を得ることを観点に, PI フィルム ${ }^{4)}$ および ABS 樹脂など5,6)の上にスパッタ法による 成膜を行った研究が行われている。 また，これらの機械的特 性や膜構造は, 高エネルギ一粒子による基板照射により影響 を受けることも知られている7-9).

このような背景の中，今後のフレキシブル電子デバイスお

\footnotetext{
* 平成27年11月17日 日本真空学会2015年11月研究例会で発表

*1 広島工業大学工学部電子情報工学科（７７31-5193 広島県広島 市佐伯区三宅 2-1-1)
}

よびプラスチック電子デバイスの更なる進展のために，イオ ン照射効果を適切に制御した成膜法の詳細を明らかにし, 膜 構造が緻密な薄膜の低温高品質成膜を可能とすることは重要 な課題の一つである.

イオン照射効果により表面拡散を起こすエネルギーは, 基 板に入射するイオンとスパッタ原子の入射束比とイオンエネ ルギーの積に依存する. 従って, これらのパラメータを制御 できる装置構成抢よび実験条件の設定が必要となる，ここ で, 効率的にイオンを基板に入射させる手法として, 誘導結 合プラズマ支援型非平衡マグネトロンスパッタ法があ る10).このスパッタ法はターゲット上部側面にソレノイド コイル，ターゲットー基板間に誘導結合プラズマ生成のため の高周波 (HF) コイルを配置した特徵を持ち, ソレノイド コイルによる基板方向への磁束密度を制御することで高密度 化されたプラズマを基板近傍まで近づけ，基板へのイオン入 射束を高めることが可能である．また，ターゲット電力の調 整は成膜速度に強く関係することから，スパッタ原子入射束 の制御に有効であると考えられる。加えて，イオンエネル ギーは, 基板バイアス電圧の印加により直接的に制御できる.

本稿では, 誘導結合プラズマ支援型非平衡マグネトロンス パッタ法 (UM-ICP) を用いて, PI フィルムおよび ABS 樹 脂上に $\mathrm{Ni}$ 薄膜を作製した研究例を紹介する．イオン照射効 果制御の観点から，PI フィルム基板には基板方向磁束密度 および基板 DCバイアス電圧を変化させ， ABS 樹脂基板に は基板方向磁束密度およびターゲット DC 電力をそれぞれ変 化させて成膜を行った．樹脂基板上への成膜に及ぼすイオン 照射効果の影響を，作製した $\mathrm{Ni}$ 薄膜の物性評価から検討し た。

\section{2. 実験方法}

Fig. 1 に実験装置構成図を示す。排気系は液体窒素卜ラ ップ，ターボ分子ポンプおよび油回転ポンプから構成されて 


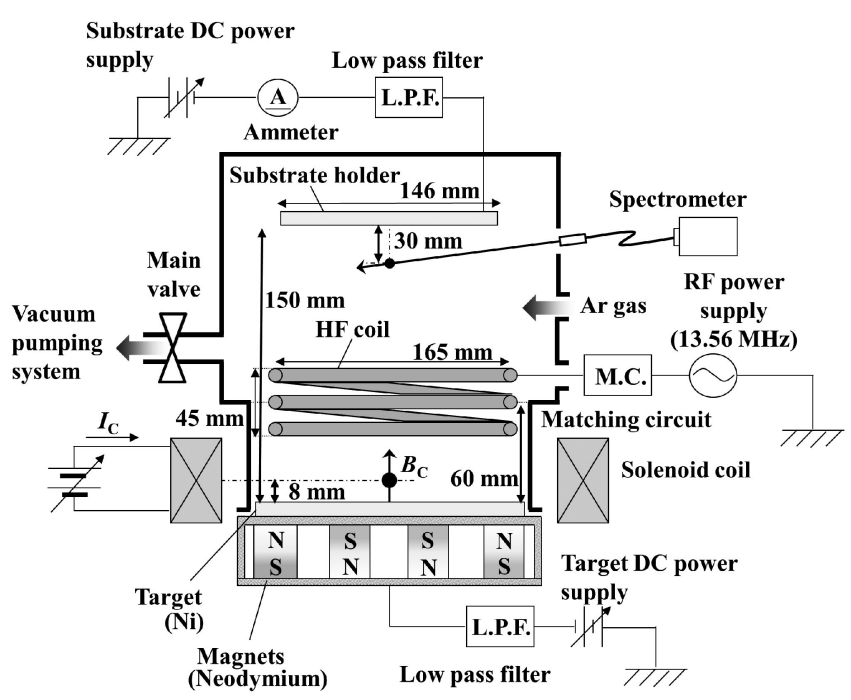

Fig. 1 Schematic diagram of the present UM-ICP sputtering system.

いる. ターゲットは, $\mathrm{Ni}$ (直径 $200 \mathrm{~mm}$, 厚さ $3,5 \mathrm{~mm}$, 純 度99.95\%)，スパッタガスは，Ar（純度99.9999\%）を用い た. 成膜時のガス流量およびスパッタガス圧力は，それぞれ $1 \mathrm{sccm}, 2.7 \times 10^{-1} \mathrm{~Pa}$ で一定とした。ターゲット上 $60 \mathrm{~mm}$ に ICP 生成用の HF コイルとして SUS304製パイプをスパ イラル状に 3 回巻いて設置した. HF コイルに印加する $\mathrm{RF}$ 電力は $30 \mathrm{~W}$ 一定とした. ターゲットー基板間は $150 \mathrm{~mm}$ と し, 直径 $146 \mathrm{~mm}$ の基板ホルダーを用いた. PI フィルム基 板のサイズは $15 \mathrm{~mm} \times 15 \mathrm{~mm} \times 25 \mu \mathrm{m}^{\mathrm{t}}$ とし, 成膜前にエタ ノールで脱脂を行った. 成膜条件としてターゲット表面から $8 \mathrm{~mm}$ の位置における外部ソレノイドコイルの中心の磁束密 度 $B_{\mathrm{C}}$ 抢よび基板 $\mathrm{DC}$ バイアス電圧 $V_{\mathrm{S}}$ をそれぞれ $0,3,5$ $\mathrm{mT}$ および $0,-40,-80 \mathrm{~V}$ と変化させた. 膜厚は全ての試 料で約750 $\mathrm{nm}$ に揃えた. ABS 樹脂基板のサイズは $15 \mathrm{~mm} \times$ $15 \mathrm{~mm} \times 1 \mathrm{~mm}^{\mathrm{t}}$ とし，成膜前に純水中で10分間の超音波洗 浄を行った。成膜条件として $B_{\mathrm{C}}$ およびターゲット DC 電力 $P_{\mathrm{T}}$ をそれぞれ 0, 3, $5 \mathrm{mT}$ および300，400，500，600，700 W と変化させた．ABS 樹脂に対しては，基板が低融点である ことを考慮して，1 分間の成膜を繰り返して行うステップ成 膜を適用した。膜厚は全ての試料で約 $200 \mathrm{~nm}$ に揃えた。 Ni 薄膜物性に及ぼすイオン照射効果を確認するため，基板表面 から30 mm の位置におけるプラズマ中のイオンの発光強度 $I_{\mathrm{ArII}}$ 抢よび基板電流 $I_{\mathrm{S}}$ をそれぞれ分光器（USB2000+： Ocean Optics 社製）および電流計により測定した． Ni 薄膜 の物性評価として, 結晶構造を X 線回折法 (XRD, CuK $\alpha_{1}$; RINT-2200V: Rigaku 社製)，表面性状を原子間力顕微鏡 (AFM; JSPM-4200: JEOL 社製)，室温での比抵抗を四探針 法，基板との密着性をテープ試験法により測定した.

\section{3. 実験結果および考察}

\section{1 イオン照射効果}

イオン照射効果により表面拡散を起こすエネルギー $E$ は 式(1)により表される.

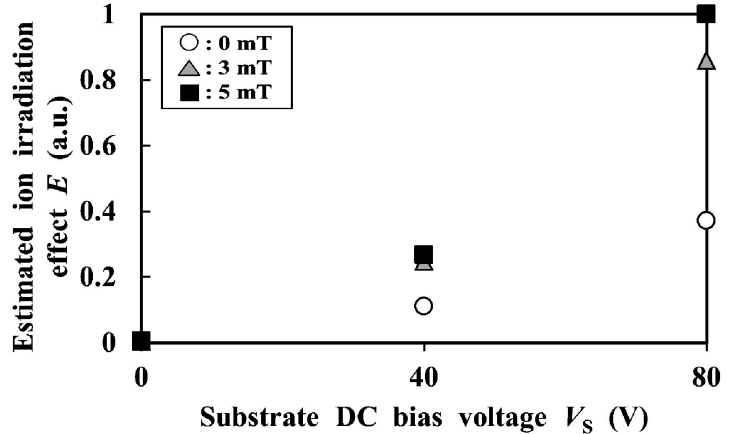

Fig. 2 Estimated ion irradiation effect $E$ as a function of substrate $\mathrm{DC}$ bias $V_{\mathrm{S}}$ and magnetic flux density $B_{\mathrm{C}}$ for $\mathrm{Ni}$ film fabricated on the PI film.

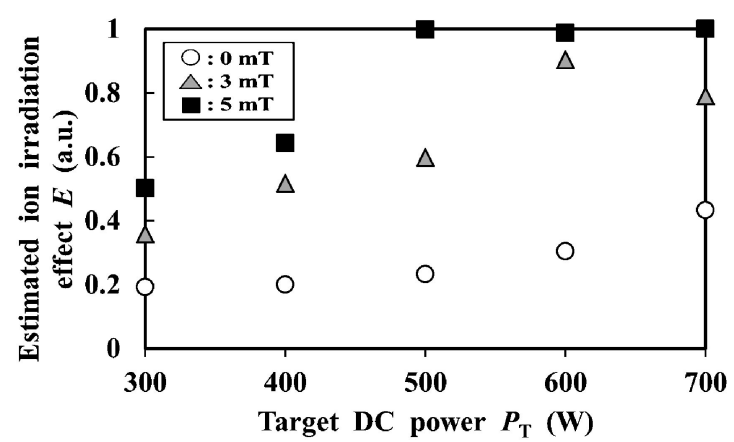

Fig. 3 Estimated ion irradiation effect $E$ as a function of target DC power $P_{\mathrm{T}}$ and magnetic flux density $B_{\mathrm{C}}$ for Ni film fabricated on the ABS resin substrate.

$$
E=\left(j_{\mathrm{i}} / j_{\mathrm{m}}\right) E_{\mathrm{j}} \quad[\mathrm{eV} / \text { atom }]
$$

ここで， $j_{\mathrm{m}}$ はスパッタ原子入射束， $j_{\mathrm{i}}$ はイオン入射束， $E_{\mathrm{j}}$ は イオンエネルギーである， $j_{\mathrm{m}}$ は成膜レートの值に対応して いる， $j_{\mathrm{i}}$ の算出には飽和したイオン電流の值が必要であるが， $V_{\mathrm{S}}$ を印加しない条件では定量的な測定が困難である。そこ で，本研究では基板近傍のArイオン発光強度 $I_{\mathrm{ArII}}$ の值を $j_{\mathrm{i}}$ として用いた。 また， $E_{\mathrm{j}}$ を求める際の印加電压は， $V_{\mathrm{S}}$ と近 似できるため, $V_{\mathrm{S}}=-40,-80 \mathrm{~V}$ では同じとした， $V_{\mathrm{S}}=0 \mathrm{~V}$ の $E_{\mathrm{j}}$ は，実験装置の基板ホルダーーアース経路に設置した ローパスフィルタおよび電流計の抵抗值および基板電流值か ら，オームの法則を用いて基板ホルダーに印加される電圧を 見積り計算した.

Fig. 2 に PI フィルム上に作製した $\mathrm{Ni}$ 薄膜に及ぼすイオ ン照射効果のエネルギー $E$ の $B_{\mathrm{C}}$ 抢よび $V_{\mathrm{S}}$ 依存性を示す. $E$ は， $B_{\mathrm{C}}$ 抢よび $V_{\mathrm{S}}$ の増加と共に大きくなる傾向を示し た.この結果から， $B_{\mathrm{C}}$ および $V_{\mathrm{S}}$ どちらの増加に対しても イオン照射効果が高められ，スパッタ原子の表面拡散による 高品質成膜が期待できる.

Fig. 3 に ABS 樹脂上に作製した $\mathrm{Ni}$ 薄膜に及ぼす $E$ の $B_{\mathrm{C}}$ および $P_{\mathrm{T}}$ 依存性を示す。 $E$ は各 $P_{\mathrm{T}}$ に扔いて， $B_{\mathrm{C}}$ の増加と 共に大きくなる傾向を示した．この傾向は，特に $P_{\mathrm{T}}=500$ $\mathrm{W}$ 以上で顕著であった。この結果から $P_{\mathrm{T}}=500 \mathrm{~W}$ 以上で $B_{\mathrm{C}}$ を増加させることでイオン照射の効果が高められること が期待される. 
以上の結果から, 各成膜条件の制御に伴い, 樹脂基板上に 作製した Ni 薄膜に及ぼすイオン照射効果が変化することが 示唆された. 次に，イオン照射効果が作製した Ni 薄膜の物 性に与える影響を検討する。

\section{$3.2 \mathrm{Ni}$ 薄膜の結晶構造}

Fig. 4 に異なる $E$ 抢よび $B_{\mathrm{C}}$ で PI フィルム上に作製した $\mathrm{Ni}$ 薄膜の X 線回折パターン解析によって算出した結晶子サ イズ $t_{(111)}$ を示す。 $t_{(111)}$ の算出には, Scherrerの式を用い た ${ }^{11)}$.

$$
t_{(111)}=k \lambda / \beta \cos \theta[\mathrm{nm}]
$$

ここで, $k$ はScherrer 定数 $(k=0.94), \lambda$ は X線の波長 $\left(\mathrm{CuK} \alpha_{1}=0.154178 \mathrm{~nm}\right), \beta$ はラジアン単位におけるピーク の半值全幅, $\theta$ は $\mathrm{Ni}(111)$ に対応したブラッグ角である. $t_{(111)}$ は $E$ の増加に対して傾向的な変化は見られなかったが, $B_{\mathrm{C}}$ の増加に伴い $t_{(111)}$ は大きくなる傾向が確認できた．これ は, $B_{\mathrm{C}}$ の増加に伴うイオン照射効果の増加により表面拡散 が促進されたためであると考えられる.

Fig. 5 に異なる $E$ および $B_{\mathrm{C}}$ で $\mathrm{ABS}$ 樹脂上に作製した $\mathrm{Ni}$ 薄膜の $t_{(111)}$ を示す. 各 $B_{\mathrm{C}}$ の $E$ の増加に対して, $t_{(111)}$ は若 干の増加傾向を, また, 高い $E$ の領域での $B_{\mathrm{C}}$ の増加に対し, $t_{(111)}$ は増加する傾向を示した. いずれの場合も, イオン照 射効果の増加に伴い, $t_{(111)}$ が増加したものと示唆される.

また, スパッタ法による成膜において, 結晶子サイズの増 加に応じて膜密度が増加する報告がされている12).

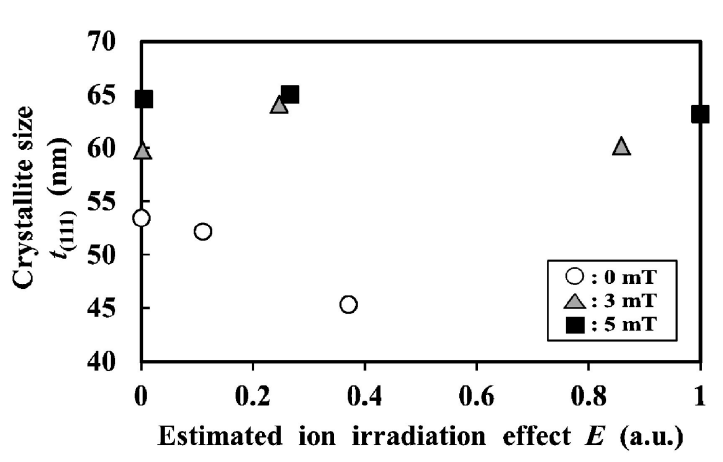

Fig. 4 Effects of estimated ion irradiation effect $E$ and magnetic flux density $B_{\mathrm{C}}$ on the crystallite size $t_{(111)}$ of the fabricated $\mathrm{Ni}$ film on the PI film.

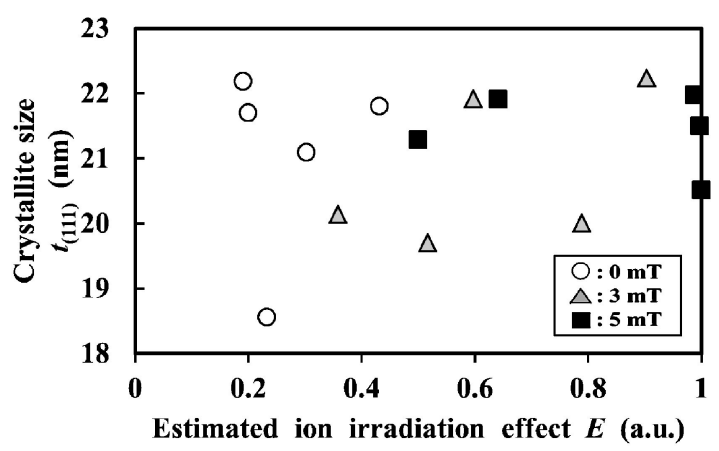

Fig. 5 Effects of estimated ion irradiation effect $E$ and magnetic flux density $B_{\mathrm{C}}$ on the crystallite size $t_{(111)}$ of the fabricated $\mathrm{Ni}$ film on the ABS resin substrate.

\section{$3.3 \mathrm{Ni}$ 薄膜の比抵抗}

Fig. 6 に，異なる $E$ および $B_{\mathrm{C}}$ で PI フィルム上に作製し た $\mathrm{Ni}$ 薄膜の比抵抗 $\rho$ を示す。 $\rho$ は， $E$ の増加に対して増加 傾向が，また， $B_{\mathrm{C}}$ の増加に対して減少する傾向を示した. これは, Fig. 4 に示したように, $B_{\mathrm{C}}$ の増加に伴いイオン照 射効果が高まり, 作製した $\mathrm{Ni}$ 薄膜は $t_{(111)}$ が大きく密な膜 構造になったためであると考えられる. $B_{\mathrm{C}}=3 \mathrm{mT}, E=$ 0.24 に打いて, 本研究に抢ける最小值の $\rho=9.0 \times 10^{-6} \Omega \mathrm{cm}$ が得られた。

Fig. 7 に，異なる $E$ および $B_{\mathrm{C}}$ で $\mathrm{ABS}$ 樹脂上に作製した $\mathrm{Ni}$ 薄膜の $\rho$ を示す. 各 $B_{\mathrm{C}}$ の $E$ の増加に対して, $\rho$ は若干の 減少傾向を, また, 高い $E$ の領域での $B_{\mathrm{C}}$ の増加に対し, $\rho$ は減少する傾向を示した.これは, Fig. 5 に示したように, 適切なイオン照射の影響により $t_{(111)}$ が増加し, 膜構造が密 になったためであると考えられる. $B_{\mathrm{C}}=5 \mathrm{mT}, E=0.98 に$ おいて ABS 樹脂上に作製した中で最も低い $\rho=1.4 \times 10^{-5}$ $\Omega \mathrm{cm}$ が得られた.

以上の結果から，PI フィルムおよび ABS 樹脂上に作製し た $\mathrm{Ni}$ 薄膜どちらに対しても，イオン照射効果の増加に伴う $t_{(111)}$ の成長の影響により膜密度が増加し， $\rho$ が減少するこ とが示された.

\section{$3.4 \mathrm{Ni}$ 薄膜の密着性}

各樹脂基板上に作製した $\mathrm{Ni}$ 薄膜と基板の密着性を調査す

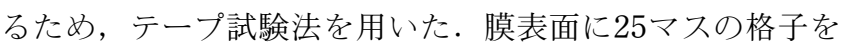
形成した後にテープを貼りつけ，テープを引き剥がした際に

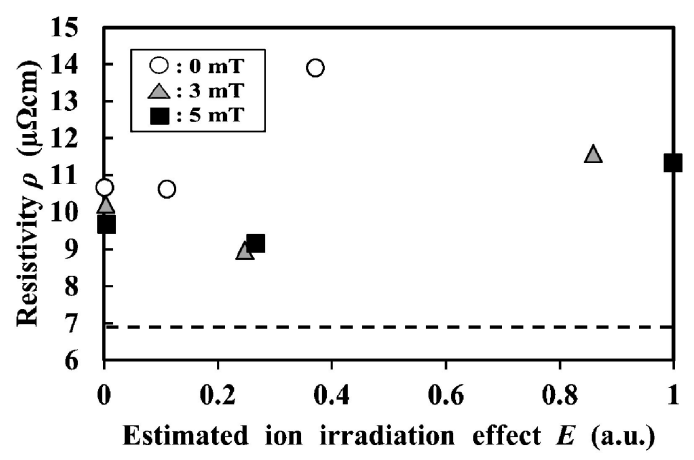

Fig. 6 Effects of estimated ion irradiation effect $E$ and magnetic flux density $B_{\mathrm{C}}$ on the resistivity $\rho$ of the fabricated $\mathrm{Ni}$ film on the PI film.

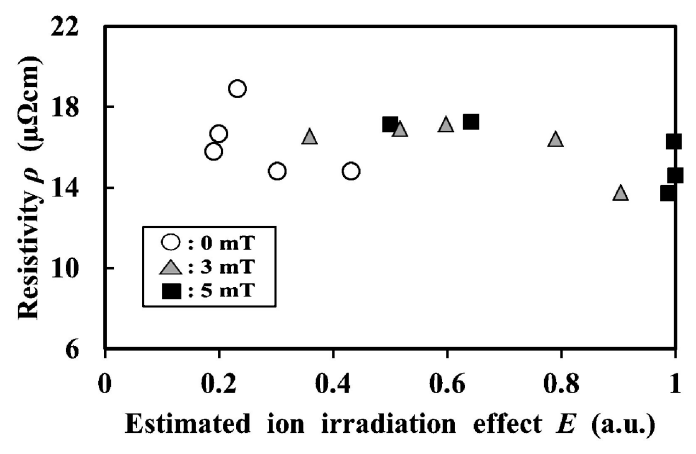

Fig. 7 Effects of estimated ion irradiation effect $E$ and magnetic flux density $B_{\mathrm{C}}$ on the resistivity $\rho$ of the fabricated $\mathrm{Ni}$ film on the ABS resin substrate. 
$\mathrm{Ni}$ 薄膜の剥離した格子の割合を剥離率 $r_{\mathrm{P}}$ として評価した.

Fig. 8 に，異なる $E$ および $B_{\mathrm{C}}$ で PI フィルム上に作製し た $\mathrm{Ni}$ 薄膜の $r_{\mathrm{P}}$ を示す。ここで， $B_{\mathrm{C}}=0 \mathrm{mT}, E=0$ における $r_{\mathrm{P}}=40 \%$ は，イオン照射効果の制御を行わない通常のマグネ トロンスパッタ法で作製したサンプルの剥離率とみなせるた め, 密着性の基準とした。

$r_{\mathrm{P}}$ は $E$ および $B_{\mathrm{C}}$ の制御に対して傾向的な変化を示さなか ったが，ほとんどの Ni 薄膜の $r_{\mathrm{P}}$ は $40 \%$ より低いことがわか る.これは, $B_{\mathrm{C}}=0 \mathrm{mT}, E=0$ に比べて, イオン照射効果 の増加により, PI フィルム上に作製した $\mathrm{Ni}$ 薄膜と基板の密 着性が向上したことを示している. 一方, $B_{\mathrm{C}}=3 \mathrm{mT}, E=$ 0.5 および $B_{\mathrm{C}}=5 \mathrm{mT}, E=1.0$ で作製した $\mathrm{Ni}$ 薄膜の $r_{\mathrm{P}}$ は， それぞれ，56\%抢よ゙ $88 \%$ であった． $B_{\mathrm{C}}=5 \mathrm{mT} ， E=1.0$ に おいて剥離率が最も高くなった原因の一つとして, Fig. 2 に 示すように $E$ が著しく増加したことにより，イオン照射効 果が過剰になったことが原因で密着性に影響したものと考え られる。

Fig. 9 に，異なる $E$ 抢よ゙ $B_{\mathrm{C}}$ で $\mathrm{ABS}$ 樹脂上に作製した $\mathrm{Ni}$ 薄膜の剥離率 $r_{\mathrm{P}}$ を示す．この結果から，すべてのサンプ ルにおいてイオン照射効果の程度に関わらず，剥離は確認で きず，基板との密着性が極めて高い $\mathrm{Ni}$ 薄膜が形成されたこ とが示された.

以上の結果から, PI フィルム上に作製した $\mathrm{Ni}$ 薄膜は, $B_{\mathrm{C}}$ および $V_{\mathrm{S}}$ によりイオン照射効果を適切に制御すること

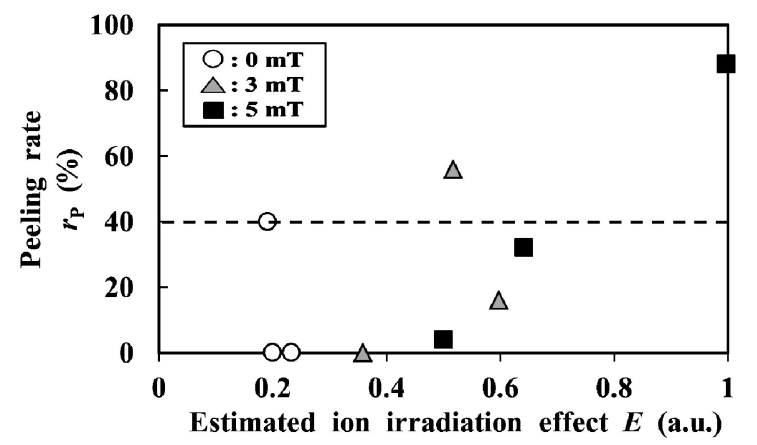

Fig. 8 Effects of estimated ion irradiation effect $E$ and magnetic flux density $B_{\mathrm{C}}$ on the peeling rate $r_{\mathrm{P}}$ of the fabricated $\mathrm{Ni}$ film on the PI film.

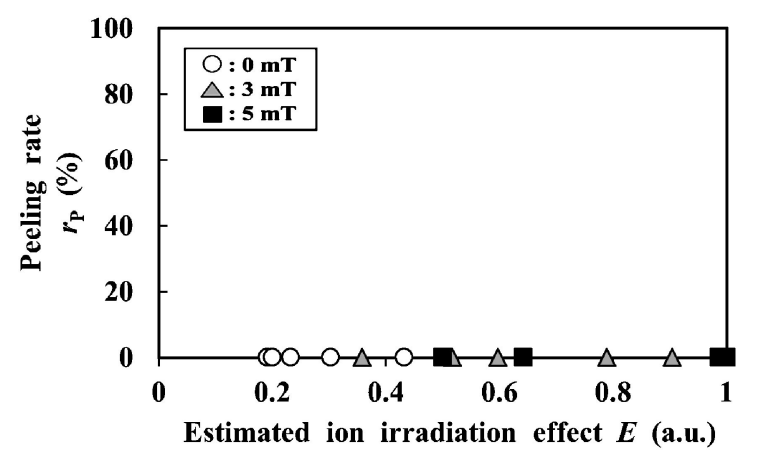

Fig. 9 Effects of estimated ion irradiation effect $E$ and magnetic flux density $B_{\mathrm{C}}$ on the peeling rate $r_{\mathrm{P}}$ of the fabricated $\mathrm{Ni}$ film on the ABS resin substrate.
で密着性が向上することがわかったＡBS 樹脂上に作製し た $\mathrm{Ni}$ 薄膜は，イオン照射効果の程度に関わらず，すべての サンプルで基板との密着性が極めて高かった.

\section{4. まと め}

UM-ICP を用いて, PI フィルムおよび ABS 樹脂上に Ni 薄膜を作製した．イオン照射効果制御の観点から，PI フィ ルム基板には $B_{\mathrm{C}}$ および $V_{\mathrm{S}}$ を変化させ， $\mathrm{ABS}$ 樹脂基板には $B_{\mathrm{C}}$ および $P_{\mathrm{T}}$ をそれぞれ変化させて成膜を行った

結果として, 基板近傍の Ar イオン発光強度, 成膜レー 卜，基板電流を用いて算出したイオン照射効果のエネルギー $E$ は, 各成膜条件の制御に伴い変化することが示唆された. 結晶構造においては，PI フィルム上に作製した Ni 薄膜は $B_{\mathrm{C}}$ の増加に関連するイオン照射効果の増加により結晶子サ イズ $t_{(111)}$ が増加することが明らかとなった. ABS 樹脂上に 作製した $\mathrm{Ni}$ 薄膜は, 各 $B_{\mathrm{C}}$ の $E$ の増加に対して, $t_{(111)}$ は若 干の増加傾向を, また, 高い $E$ の領域での $B_{\mathrm{C}}$ の増加に対し, $t_{(111)}$ は増加する傾向が示された. 比抵抗においては, PI フ ィルム上および ABS 樹脂上に作製した $\mathrm{Ni}$ 薄膜どちらに対 してもイオン照射効果の増加に伴う $t_{(111)}$ の成長の影響によ り膜密度が増加し, 比抵抗 $\rho$ が減少することが示された。 密着性に拈いては, PI フィルム上に作製した Ni 薄膜は, $E$ および $B_{\mathrm{C}}$ によりイオン照射効果を適切に制御することで密 着性が向上し, $\mathrm{ABS}$ 樹脂上に作製した Ni 薄膜は, イオン照 射効果の程度に関わらず，すべてのサンプルで剥離が確認さ れず，基板との密着性が極めて高かった.

これらの結果から，基板は異なるがイオン照射効果により 樹脂基板上に作製した $\mathrm{Ni}$ 薄膜の膜質制御が可能であること が確認された. 本研究から得られた知見は今後の樹脂基板上 へのデバイス開発の発展に寄与することが期待される.

\section{[文献 $]$}

1) J. Perrenoud, B. Schaffner, S. Buecheler and A. N. Tiwari: Sol. Energy Mater. Sol. Cells, 95 (2011) S8.

2) M. Kaltenbrunner, T. Sekitani, J. Reeder, T. Yokota, K. Kuribara, T. Tokuhara, M. Drack, R. Schwödiauer, I. Graz, S. Bauer-Gogonea, S. Bauer and T. Someya: Nature, 499 (2013) 458.

3) H. Kobayashi: in Supattahakumaku (Nikkan Kogyo Shimbun Ltd., Tokyo, 1993) p. 77 [in Japanese].

4) F. Macionczyk and W. Bruckner: J. Appl. Phys., 86 (1999) 4922.

5) T. Tsukada and N. Hosokaw: J. Vac. Sci. Technol., 16 (1979) 348.

6) K. De Bruyn, M. Van Stappen, H. De Deurwaerder, L. Rouxhet and J. P. Celis: Surf. Coat. Technol., 163-164 (2003) 710.

7) D. M. Mattox: J. Vac. Sci. Technol. A, 7 (1989) 1105.

8) S. M. Rossnagel and J. J. Cuomo: Thin Solid Films, 171 (1989) 143.

9) A. Anders: Thin Solid Films, 518 (2010) 4087.

10) R. Eboshi, Y. Muraoka, S. Kurokawa, A. Tachibana, Y. Hasui and K. Kawabata: J. Vac. Soc. Jpn., 51 (2008) 182.

11) G. Matsumura: in Ekkususenkaisetuyouron (Agune Ltd., Tokyo, 1961) p.101 [in Japanese].

12) T. Koda and H. Toyota: J. Vac. Soc. Jpn., 58 (2015) 257. 